\title{
Azathioprine in chronic relapsing idiopathic polyneuropathy
}

\author{
B. Pentland \\ B.Sc., M.B., Ch.B., M.R.C.P. \\ Edinburgh University Department of Medical Neurology, Northern General Hospital, Ferry Road, \\ Edinburgh
}

\begin{abstract}
Summary
A 33-year-old housewife with a 14-year history of relapsing polyneuropathy of unknown cause who has apparently responded to azathioprine therapy is described. The place of this form of treatment in idiopathic polyneuropathy is discussed.
\end{abstract}

\section{Introduction}

A chronic relapsing polyneuropathy similar in clinical and laboratory findings to the acute polyneuropathy of Guillain-Barré has been increasingly recognized in recent years (Thomas et al., 1969; Ashworth and Smyth, 1969; Dyck et al., 1975). The efficacy of steroid therapy in the acute syndrome has been questioned recently (Hughes et al., 1978) but it does appear to have a place in the treatment of some chronic cases (Austin, 1958; Thomas, 1975). Other forms of immunotherapy are being evaluated including azathioprine therapy.

A patient who appears to have responded to azathioprine therapy is described and the literature on its use in chronic idiopathic neuropathy is reviewed.

\section{Case report}

The patient, then an 18-year-old shop assistant, first presented in December 1964 with a 6-week history of weakness of grip, clumsiness of hands, and an intermittent weakness of the legs. Examination revealed sluggish tendon jerks and variable limb weakness. She had increasing difficulty climbing stairs over the next 6 months, and CSF protein was then $0.82 \mathrm{~g} / 1$ with no increase in cells. Without therapy she gradually regained full function over the following few months. In February 1967, however, she was referred with a 2-week history of tired and 'heavy' limbs on the right side, and depression. Antidepressant therapy appeared effective, she became pregnant and by May was much improved. Four months later, in the third trimester of her pregnancy, she developed generalized weakness of all limbs, dysphagia, exertional dyspnoea and paraesthesiae in the extremities. There was bilateral facial palsy, palatal palsy, profound weakness of all 4 limbs more marked proximally, impaireg sensation in the right hand and areflexia. She w admitted and within 2 days she was bed-bount requiring help with feeding although her respiratorg function remained adequate. Her CSF protein w $1 \cdot 19 \mathrm{~g} / \mathrm{l}$ with no increase in cells.

ACTH was started in a dosage of $120 \mathrm{mg}$ daily and within 2 days there was marked improvement which was maintained and she proceeded to a successfut delivery, leaving hospital with only slight generaj weakness and able to nurse her child, and walk without support. A relapse occurred in March 1968 with a less impressive response to a 9-week course of ACTH. She was maintained satisfactorily on frat prednisolone until the following January, dufing which time she was able to do light housework to walk unsupported. Four months later, she deteri rated. Response to a further course of ACTH was poor. Towards the end of 1969 , without treatmer she gradually improved and during the followin year her only complaint was of intermittent paraes? thesiae. She became pregnant again and in Marcs 1971 she had a bout of generalized weakness lasting about 2 months, which resolved without treatmen Her disability was slight and static for the remainder of that year, but in early 1972 there was a gradu贯 increase in weakness and paraesthesiae with some. dysphagia. She responded rapidly to a 5-day course of dexamethasone only to relapse when it was stopped.

In June 1972 azathioprine was given for exactly weeks in daily doses of 100 to $200 \mathrm{mg}$. There was ne significant response although 2 months after treat ment was stopped she was doing light housework and walking unaided. She relapsed rapidly one mont 5 later and showed little benefit from a further courses of ACTH.

Over the next 5 years her condition followed $\stackrel{\mathscr{A}}{\mathcal{O}}$ pattern of relapses lasting from one to 6 months with partial remissions of one to 4 months. During this time she received courses of ACTH, tetracen sactrin, dexamethasone and prednisolone without lasting benefit. Short courses of high dose i. 5 methylprednisolone on 3 occasions seemed dramat 
tically effective, but she rapidly relapsed on its withdrawal. In late 1975 weekly BCG immunostimulation appeared successful initially, but was withdrawn after 5 months when she showed deterioration despite it. Transfer factor injections from a matched patient who had successfully recovered from Guillain-Barré syndrome were unsuccessful in 1976.

During the late summer and autumn of 1977 she had shown a slow downward trend and in November was urgently admitted with a profound relapse. She could barely move her limbs, had diplopia in all directions of gaze, facial and palatal palsy with marked dysphagia and increasing breathlessness. Steroid therapy was instituted and she required ventilation. Once spontaneous respiration and oral medication was possible, azathioprine $200 \mathrm{mg}$ daily was started. Within 3 weeks, however, she had deteriorated again and required repeat ventilation. In late December it was possible to start the azathioprine again and gradually withdraw steroids. There was no dramatic response, but she did show a slow upward trend and left hospital using a walking frame. By the following June her improvement was marked and she was walking unaided, doing more and more housework. She has since been maintained on azathioprine with minor alterations in dosage in response to her blood and platelet count. At the time of writing, December 1979, her power in all 4 limbs is almost normal and all her reflexes have returned. Her only symptoms are slight intermittent paraesthesiae in the extremities.

She has been extensively investigated for known causes of peripheral neuropathy including repeated checks for porphyria, vitamin deficiency, metabolic and autoimmune disorders. Although her clinical response is clear and her FEV and FVC are now normal, her motor nerve conduction velocities are still markedly slow (distal velocities for left ulnar and right lateral popliteal nerves, respectively, $13 \mathrm{~m} / \mathrm{sec}$ and $27 \mathrm{~m} / \mathrm{sec}$ in 1967; $15 \mathrm{~m} / \mathrm{sec}$ and $26 \mathrm{~m} / \mathrm{sec}$ in 1972; $26 \mathrm{~m} / \mathrm{sec}$ and $25 \mathrm{~m} / \mathrm{sec}$ in 1979).

\section{Discussion}

Three cases of chronic idiopathic polyneuropathy treated with azathioprine have been described. Yuill and colleagues described 5 acute polyneuropathies who improved with azathioprine and one chronic case who did not (Yuill, Swinburn and Liversedge, 1970). The latter case was a 55-year-old man with a 3-year history of polyneuropathy who was unable to tolerate the drug because of dyspepsia and it was stopped within a few days with no benefit. A 58year-old woman who suffered from relapsing polyneuropathy for more than 3 years repeatedly responded to corticotrophin injections; she was given azathioprine for 6 months without improvement although a subsequent course of corticotrophin again produced a rapid response (Heathfield and Dallos, 1970). More recently a 54-year-old female patient with a 2-year history of polyneuropathy was described in Poland (Prusinski, Szulc-Kuberska and Zawadski, 1978). This woman was unable to walk without support, had difficulty with manual tasks and marked glove and stocking anaesthesia. Steroid therapy was ineffective but she improved within one month of starting azathioprine $100 \mathrm{mg}$. daily and was walking unaided after 2 months. Her improvement was maintained during the ensuing 9 months of therapy.

The patient described here had a relapsing chronic polyneuropathy for 14 years. For the first 6 years of her illness she had occasional remissions lasting from 2 to 12 months. During the next 6 years there were only short periods of improvement of minor degree until the institution of azathioprine therapy since when she has shown a substantial improvement for 2 years. The delay of 6 months after starting the drug before there was unequivocal improvement is compatible with the action of azathioprine and in keeping with experience of its use in other conditions. It is possible that the treatment merely coincided with a spontaneous recovery from the disease. The use of azathioprine in chronic idiopathic polyneuropathy needs further appraisal, including multicentre controlled trials.

\section{Acknowledgments}

I am grateful to Dr C. Mawdsley for his advice and permission to study his patient and to Dr Kraszewski for his help in translation.

\section{References}

Ashworth, B. \& Sмyth, G.E. (1969) Relapsing motor polyneuropathy. Acta neurologica scandinavica, 45, 342.

AUSTIN, J.H. (1958) Recurrent polyneuropathies and their corticosteroid treatment. Brain, 81, 157.

Dyck, P.J., Lais, A.C., Ohta, M., Bastron, J.A., Okazaki, H. \& Groover, R.V. (1975) Chronic inflammatory polyradiculoneuropathy. Proceedings. Mayo Clinic, 50, 621.

Heathfield, K. \& Dallos, V. (1970) Treatment of polyneuropathy with azathioprine. Lancet, ii, 1030.

Hughes, R.A.C., Newsom-Davis, J.M., Perkin, G.D. \& PIERCE, J.M. (1978) Controlled trial of prednisolone in acute polyneuropathy. Lancet, ii, 750.

Prusinski, A., Szulc-Kuberska, J. \& Zawadzki, Z. (1978) A case of chronic Guillain-Barré syndrome treated successfully with azathioprine. Wiadomości lekarskie, 31, 1545.

TномAs, P.K. (1975) Recent Advances in Clinical Neurology, (Ed by Matthews, W.B.), p. 269. Churchill-Livingstone, Edinburgh.

Thomas, P.K., Lascelles, R.G., Hallpike, J.F. \& Hewer, R.L. (1969) Recurrent and chronic relapsing GuillainBarré polyneuritis. Brain, 92, 589.

Yuill, G.M., Swinburn, W.R. \& Liversedge, L.A. (1970) Treatment of polyneuropathy with azathioprine. Lancet, ii, 854. 